\title{
Method of Comprehensive Estimation of Natural and Anthropogenic Territory Safety in the Case of Krasnoyarsk Region
}

\author{
Tatiana Penkova ${ }^{1,2}$, Anna Metus ${ }^{1}$ \\ ${ }^{1}$ Institute of Computational Modelling of the Siberian Branch \\ of the Russian Academy of Sciences, 50/44 Akademgorodok, Krasnoyarsk, 660036, Russia \\ ${ }^{2}$ Siberian Federal University, 79 Svobodny pr., 660041 Krasnoyarsk, Russia \\ \{penkova_t, metus, \} @icm.krasn.ru
}

\begin{abstract}
This paper presents a new technique of comprehensive analytical estimation of natural and anthropogenic territory safety based on the creation of a geographically-oriented safety standard and integral assessment of the state of environment and technosphere objects. The standard presents a normative model that provides a correct estimation of territory safety taking into account its individual characteristics. The basic elements and principles of territory safety standard creation are suggested in this paper. In order to estimate territory safety, the authors propose an algorithm to calculate the estimate of territory safety as an integral estimate of the comprehensive indicator based on the multidimensional estimates of the basic indicators using the results of on-line analytical processing of monitoring data. In contrast to existing methods, the proposed algorithm uses the ranges of the normative values and assesses the significance of indicators change relative to standard ranges, it allows us to regulate the velocity of estimates change when the actual values of the indicators deviate from the normative ranges. Also, the author's technique is oriented at forming the multidimensional estimates in the context of several observation points. Proposed solutions are described through their application to the territories of the Krasnoyarsk region.
\end{abstract}

Keywords: Prevention of Emergencies, Estimation of Natural and Anthropogenic Safety, Geographically-Oriented Standard, Territorial Management

\section{Introduction}

Early prevention of natural and anthropogenic emergencies is a major factor for effective territory safety management [1-5]. To decrease the risk of emergencies one has to provide comprehensive monitoring of the current processes, adequate assessment of the state of territory safety and reasonable decision-making process. A lot of studies show that the management of territory safety should be carried out in two basic directions: operational and strategic control [6 -7]. The operational control provides permanent monitoring of parameters of the state of environment and technosphere objects, detection of preconditions for occurrence of emergencies; it is aimed at organis- 
ing preventive measures to exclude some possible accidents or mitigate their consequences. In contrast, the strategic control is focused on reducing the overall risk in the territory; it provides collection, storage and comprehensive analysis of safety indicators; it is aimed at planning activities and developing management recommendations for risk reduction, improving the organisational structure of the subdivisions responsible for elimination of emergencies. To deal with the problems of increasing the safety of vital activity of the population and territories, the operational control systems are being actively introduced [8-10]. At present, online observation networks for potential sources of emergencies are created, weather and seismic stations are unfolded within the territory, different control sensors and video monitoring systems are being introduced at various facilities. Apart from the on-line monitoring tools, the theoretical research in the field of strategic control of the territory safety is also developed actively. In Russia as well as in the world, there are a large number of studies related to methods of risk analysis, current state assessment and emergency prediction. However, as usual, natural and technogenic processes are considered independently that makes it difficult to assess the situation comprehensively taking into account the influence of many factors [11]. Generally, three principal approaches are used to assess the state of territory safety. The first one, a probabilistic approach, makes it possible to calculate an estimate of the emergency risk by applying the mathematical models that link the presuppositions with a probability of event's occurrence. Methods of this type are used to calculate individual, collective and social risks and, as a rule, they are oriented to specific technical objects. Application of these methods to the territories requires the improvement of the regulatory base and significant adaptation of computational models. The second one, a statistical approach, allows for forming quantitative estimates based on data analysis for certain period of observation. Advantages of methods of this type include their objectivity, ability to investigate the dynamic of changes of the observed parameters and form the summary indicators. However, these methods cannot be used for rarely observed events, they do not allow to obtain the operational estimates of the current state and, moreover, do not give the possibility to interpret the quantitative estimates. The third one, a heuristic approach, allows for forming the qualitative assessments when the formal methods are too complicated and the initial database is insufficient to obtain a univocal analytical solution. In addition, application of methods of this type without analytical support leads to some errors of a subjective nature. Thus, the above considered confirms the topicality and necessity of the hybrid approach that makes it possible to have the comprehensive assessments of natural and technogenic territory safety taking into account the specific influence of risk factors on each other and their temporal development for the particular territory.

The outline of this paper is as follows: Section 1 contains the introduction. Section 2 describes the author's method of comprehensive analytical estimation of natural and anthropogenic territory safety. Creation of the safety standard is described here in detail using particular examples for Krasnoyarsk territories. Section 3 presents a new algorithm for calculation of integral estimation of the territory safety. Section 4 demonstrates some results of algorithm application. Conclusion comprises the basic outcomes and tasks for future research. 


\section{Comprehensive Estimation of Natural and Anthropogenic Territory Safety}

\subsection{The object of study}

The Krasnoyarsk region is the second largest federal subject of Russia and the third largest subnational governing body by area in the world. The Krasnoyarsk region lies in the middle of Siberia and occupies an area of 2.4 million square kilometres, which is $13 \%$ of the country's total territory. This territory is characterised by a heightened level of natural and technogenic emergencies which is determined by social-economic aspects, large resource potential, geographical location and climatic conditions. According to the annual report of the Krasnoyarsk Ministry of Emergency [12, 13], in the territory there are many accident prone technosphere objects: 2 radiation-related objects; 45 chemically-dangerous objects; 89 fire-hazardous and dangerously explosive objects; almost 500 hydraulic facilities that have been in operation for more than 30 years; 9 critically important objects, a lot of survival objects including boiler plants, power plants, pipelines and networks. Moreover, the territory is located in seven climatic zones. A number of large-scale natural emergencies are recorded each year, namely: flood, forest fire, gale-strength wind, anomalously low temperature and snow avalanche.

Therefore, operational and strategic monitoring, as well as the estimation of the state of environment and technosphere objects, are extremely actual problems for Krasnoyarsk region. The solution of these issues should be based on a comprehensive consideration of risk factors taking into account the singularity of the territories and formation of an integral estimate of the state which can be detailed to identify abnormal situations.

\subsection{The technique of comprehensive estimation of natural and anthropogenic territory safety}

The new technique of comprehensive estimation of natural and anthropogenic territory safety is based on creation of a geographically-oriented safety standard and integral assessment of the state of environment and technosphere objects [14].

Creation of the natural and anthropogenic territory safety standard - is a process of developing a geographically-oriented normative model that is required for correct estimation of the actual state of territory safety and presents the safety target level based on the individual characteristics of the territory and the real possibilities of its achievement [15]. The standard is developed by experts using federal, regional normative specifications and data analysis results [16]. Figure 1 presents the IDEF0 diagram of the standard creation process. IDEF0 model describes the functions (e.g. activities, actions, processes or operations); inputs and outputs as the data needed to perform the function and the data that is produced as a result of the function respectively; controls which constrain or govern the function and mechanisms which can be thought of as a person or device which performs the function. 
Integral estimation of the state of natural and anthropogenic territory safety - is a process of calculating the integral estimate of the comprehensive indicator based on the hierarchy of estimates of basic indicators using the results of on-line analytical processing of monitoring data. This process is performed by OLAP-system in accordance with the created standard and author's algorithm. Figure 2 presents the IDEF0 diagram of the territory safety estimation process.

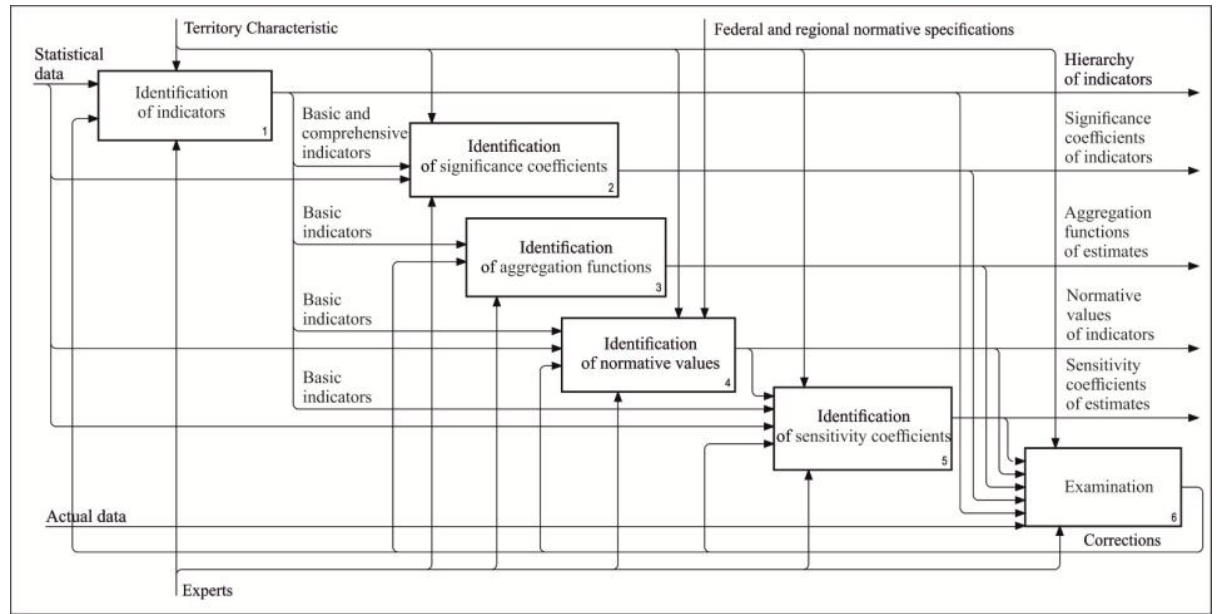

Fig. 1. IDEF0 diagram of creation of the natural and anthropogenic territory safety standard.

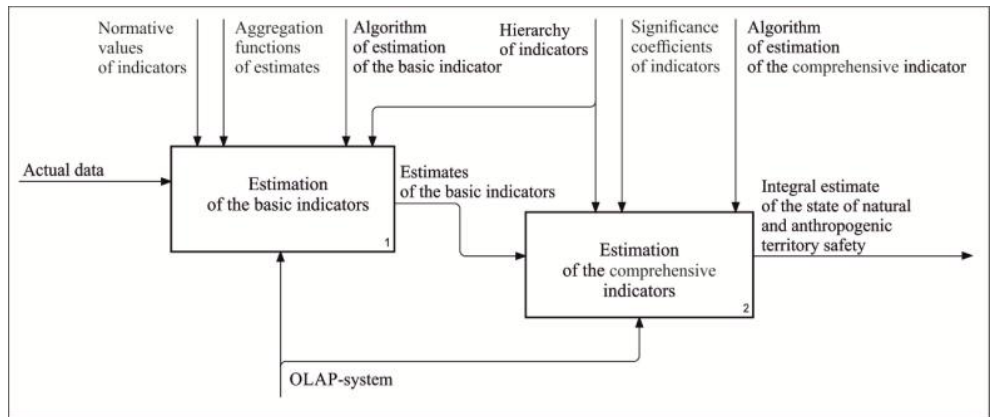

Fig. 2. IDEF0 diagram of integral estimation of the state of territory safety.

Creation of the natural and anthropogenic territory safety standard. This process consists of the following basic stages:

- Identification of indicators

- Identification of significance coefficients

- Identification of aggregation function

- Identification of normative values

- Identification of sensitivity coefficients 
Identification of indicators - is a process of forming the hierarchy of indicators that characterise the natural and anthropogenic risk factors for emergencies [17]. The hierarchy contains two types of indicators: the basic indicators - a set of primary statistical indicators that are formed by OLAP-models and present the lowest level of hierarchy, and the comprehensive indicators - a set of aggregation levels of basic indicators in accordance with monitoring fields that present the intermediate and upper levels of the hierarchy. Figure 3 shows an example of comprehensive indicators for territory safety control.



Fig. 3. An example of comprehensive indicators for territory safety control.

Identification of significance coefficients - is a process of calculating the relative weights $\left(u_{k}\right)$ that characterise the contribution of the lower-level indicators of the hierarchy to the upper-level indicators $\left(u_{k}>0, \sum u_{k}=1\right)$. Significance coefficients are determined for each territory taking into account its physical, geographical and socio-economic characteristics. Table 1 presents an example of significance coefficients for two territories: for the municipal area in the central part of the region as a metropolis (Krasnoyarsk area) and for the municipal area with intensive mining of minerals in the northern part of the region (Turukhansky area).

Identification of aggregation function - is a process of determining the functions $\left(f_{a g r}^{k}\right.$ ) that provide a transition from multidimensional estimates (i.e. in the context of several observation points) to one-dimensional estimates (i.e. in the context of territory as a whole). The aggregation function (e.g. minimum, maximum, average) is determined by the trend (i.e. the level of safety increases the increase of decrease in the values of the indicators) and the qualitative features of indicators (i.e. the worst recorded value of indicator has a greater or lesser impact on the estimate of indicator). For example, the "average" aggregation function is signed for indicators of radiation and geophysical situations and the "maximum" aggregation function is signed for indicators of the meteorological and hydrological situations. 
Table 1. An example of significance coefficients.

\begin{tabular}{lcc}
\hline \multirow{2}{*}{ Indicator } & \multicolumn{2}{c}{ Significance coefficients } \\
& Krasnoyarsk area & Turukhansky area \\
\hline Anthropogenic safety & 0.8 & 0.4 \\
$\quad$ Situation on the technosphere objects & 0.35 & 0.2 \\
$\quad$ Situation on the transport & 0.3 & 0.2 \\
$\quad$ Situation on the municipal facilities & 0.1 & 0.3 \\
Fire situation & 0.1 & 0.2 \\
$\quad$ The number of household and indus- & 0.4 & 0.3 \\
$\quad$ trial fires per 10,000 population & & \\
$\quad$ The number of fires with deaths per & 0.3 & 0.3 \\
10,000 population & & 0.4 \\
$\quad$ The number of fires with casualties & 0.3 & 0.1 \\
$\quad$ per 10000 population & 0.15 & 0.7 \\
Radiation situation & 0.2 & 0.2 \\
Natural safety & 0.3 & 0.3 \\
Meteorological situation & 0.2 & 0.05 \\
Hydrological situation & 0.3 & 0.45 \\
Geophysical situation & 0.2 & \\
Forest fire conditions & &
\end{tabular}

Identification of normative values - is a process of determining the range of normative values of indicators taking into account their multidimensionality ( $\left.\left[N_{j}^{k} ; Z_{j}^{k}\right]\right)$.

The normative values of indicators characterise the normal state of safety using statistical data analysis results. The range of normative values is identified by statistical characteristics such as median $\left(P_{j M e}^{k}\right)$ and standard deviation $\left(\sigma_{j}^{k}\right)$ as follows [18]:

$$
\left[N_{j}^{k} ; Z_{j}^{k}\right]=\left\{\begin{array}{l}
{\left[0 ; P_{j M e}^{k}+\sigma_{j}^{k}\right], \quad \text { if } P_{j M e}^{k}-\sigma_{j}^{k}<0} \\
{\left[P_{j M e}^{k}-\sigma_{j}^{k} ; P_{j M e}^{k}+\sigma_{j}^{k}\right], \quad \text { if } P_{j M e}^{k}-\sigma_{j}^{k}>0}
\end{array}\right.
$$

For example, for Turukhansky area the normative rages of "Number of events "Abnormally cold weather" indicator are the following: [0;4] for such points of observation as Bor, Vorogovo and Igarka; [1;3] for such points of observation as Vereshchagino, Kureika and Turukhansk; [1;2] for such points of observation as Svetlogorsk and Yanov Stan; [0;5] for Soviet Rechka; [0;3] for Verkhneimbatsk; [0;2] for Kellog.

Identification of sensitivity coefficients - is a process of determining the coefficients $\left(q_{k}\right)$ that regulate the velocity of estimate change when the actual value of the indicator deviates from the normative value. The sensitivity coefficient takes the following values: $0<q<1$ when the velocity of estimate change should increase with 
the increase in the deviation of the actual indicator value from the normative; $q>1$ when the velocity of estimate change should decrease with the increase in the deviation of the actual indicator value from the normative and $q=1$ when the velocity of estimate change outside the normative should remain constant.

For example, for basic indicators of the fire situation there are the following values of sensitivity coefficients: $q=0.3$ for "The number of fires with deaths per 10,000 population" indicator; $q=0.8$ for "The number of fires with casualties per 10,000 population" indicator and $q=1$ for "The number of household and industrial fires per 10,000 population" indicator.

The process of creating the safety standard is completed by an examination where experts can check the normative model by applying it to actual data and making the necessary corrections. The detailed technique of safety standard development, its principles, rules and normative values for the Krasnoyarsk region territories are presented in the work [15].

Integral estimation of the state of natural and anthropogenic territory safety. This process consists of the following basic stages:

- Estimation of the basic indicators

- Estimation of the comprehensive indicators

Estimation of the basic indicators - is a process of calculating the multidimensional estimates of the basic indicators in the context of several observation points and aggregating these estimates across the territory in accordance with the set function. Estimates of the basic indicators characterise the correspondence of the actual values to the normative and allow for estimating the significance of indicators change relative to the standard range taking into account the indicators multidimensionality and estimates sensitivity. The calculation of multidimensional estimates is performed in the form of OLAP-models.

Estimation of the comprehensive indicators - is a process of calculating the integral estimates of the comprehensive indicators using estimates of the basic indicators and their significance coefficients.

Estimation of the basic and comprehensive indicators is performed by applying the safety standard in accordance with the proposed algorithm.

\section{Algorithm of the Integral Estimation of the State of Natural and Anthropogenic Territory Safety}

The algorithm of the integral estimation of the state of natural and anthropogenic territory safety presents the development of the author's method of wellbeing estimation $[19,20]$ with the addition of OLAP-models to the hierarchy of formation of the comprehensive indicator: the integral estimates are calculated on the basis of multidimensional estimates of indicators using the multidimensional normative values. In 
addition, the proposed algorithm takes into account the velocity of estimate change when the actual value of the indicator deviates from the normative value.

The integral estimate of the comprehensive indicator is calculated using the estimates of the basic indicators and their significance coefficients as follows:

$$
I_{\Sigma}=\sum_{k=1}^{n} u_{k} I_{k}
$$

where $I_{\Sigma}-$ is an integral estimate of the comprehensive indicator; $I_{k}-$ is an estimate of $k$-th basic indicator; $u_{k}$ - is a significance coefficient of $k$-th indicator set in the standard; $n$-is a number of indicators at the same level of the hierarchy.

The estimate of the basic indicator is calculated as an aggregation of the multidimensional estimates of the indicator as follows:

$$
I_{k}=f_{\text {agr }}^{k}\left(i_{1}^{k}, \ldots, i_{m}^{k}\right)
$$

where $i_{j}^{k}, j \in\{1 \ldots m\}$ - is a multidimensional estimate $k$-th basic indicator calculated in $j$-th observation point; $f_{a g r}^{k}-$ is an aggregation function for $k$-th basic indicator set in the standard.

The multidimensional estimates of the basic indicator are calculated in the form of OLAP-model and characterise the compliance of the actual values to the normative in the context of individual observation points. The multidimensional estimates are calculated as follows:

$$
i_{j}^{k}=1+\Delta P_{j}^{k} S_{j}^{k}
$$

where $S_{j}^{k}= \pm 1-$ is a coefficient which reflects the trend of $k$-th indicator, $S_{j}^{k}=1$ when the safety state is improving with an increase in the value of the indicator, $S_{j}^{k}=-1$ when the safety state is improving with a decrease in the value of the indicator; $\Delta P_{j}^{k}-$ is a compliance coefficient of actual values of $k$-th indicator with normative in $j$-th observation point.

Compliance coefficient is calculated by:

$$
\Delta P_{j}^{k}=\left\{\begin{array}{l}
\left(\frac{P_{j}^{k}-Z_{j}^{k}}{Z_{j}^{k}-N_{j}^{k}}\right)^{q_{k}}, \quad \text { if } P_{j}^{k}>Z_{j}^{k} \\
-\left(\frac{N_{j}^{k}-P_{j}^{k}}{Z_{j}^{k}-N_{j}^{k}}\right)^{q_{k}}, \quad \text { if } P_{j}^{k}<N_{j}^{k}
\end{array}\right.
$$


where $q_{k}$-is a sensitivity coefficient of estimate for $k$-th indicator set in the standard; $\left[N_{j}^{k} ; Z_{j}^{k}\right]$ - is a range of normative values for $k$-th indicator in $j$-th observation point set in the standard; $N_{j}^{k}-$ is a lower limit of the range; $Z_{j}^{k}$-is an upper limit of the range; $P_{j}^{k}$ - is an actual value of $k$-th indicator in $j$-th observation point.

In the case when the actual value of indicator falls within the range, the compliance coefficient $\Delta P_{j}^{k}=0$; In the case when the actual value of indicator is above the upper limit of the range, the compliance coefficient has a positive value $\Delta P_{j}^{k}>0$; In case when the actual value of indicator is below the lower limit of the range, the compliance coefficient has a negative value $\Delta P_{j}^{k}<0$. The value of the coefficient $\Delta P_{j}^{k}$ in combination with the value of the coefficient $S_{j}^{k}$ makes it possible to obtain a quantitative estimate of the indicator. As a result, the value of estimate can be identified as $i_{j}^{k}>1$ that demonstrates a significant improvement of indicator.

Thus, the generated hierarchy of estimates allows for obtaining comprehensive quantitative characteristics of the state of territory safety, performing a comparative analysis with other territories and, if necessary, detailing the estimates for particular monitoring fields and indicators that give us the opportunity to identify the underlying causes of the current state. In contrast to the existing approaches, the proposed solution allows for calculating geographically-oriented estimates. The algorithm calculates integral estimates based on multi-dimensional estimates of indicators using the multidimensional normative values and takes into account the velocity of estimate change when the actual value of the indicator deviates from the normative value.

\section{Application of the Algorithm for Integral Estimation of the State of Natural and Anthropogenic Territory Safety}

Let us consider the example of integral estimation of "Fire situation" comprehensive indicator for the Krasnoyarsk area that consists of two subareas (i.e. two points of observation): Krasnoyarsk city and Peschanka village (Table 2).

Table 2. Example of integral estimation of "Fire situation" comprehensive indicator for Krasnoyarsk area.

\begin{tabular}{|c|c|c|c|c|c|c|}
\hline $\begin{array}{l}\text { Indicators / } \\
\text { Observation } \\
\text { points }\end{array}$ & $\begin{array}{c}\text { Signifi- } \\
\text { cance } \\
\text { coeffi- } \\
\text { cient, } \\
u_{k}\end{array}$ & $\begin{array}{c}\text { Sensitivity } \\
\text { coefficient, } \\
q_{k}\end{array}$ & $\begin{array}{c}\text { Lower } \\
\text { limit of } \\
\text { normative } \\
\text { range, } \\
N_{j}^{k}\end{array}$ & $\begin{array}{c}\text { Upper } \\
\text { limit of } \\
\text { normative } \\
\text { range, } \\
Z_{j}^{k}\end{array}$ & $\begin{array}{c}\text { Actual } \\
\text { value, } \\
P_{j}^{k}\end{array}$ & $\begin{array}{c}\text { Estimate, } \\
I_{\Sigma}, I_{k}, \\
i_{j}^{k}\end{array}$ \\
\hline $\begin{array}{l}\text { Fire situa- } \\
\text { tion }\end{array}$ & 0.12 & - & - & - & - & 0.47 \\
\hline
\end{tabular}




\begin{tabular}{|c|c|c|c|c|c|c|}
\hline $\begin{array}{l}\text { 1. The num- } \\
\text { ber of } \\
\text { household } \\
\text { and indus- } \\
\text { trial fires } \\
\text { per } 10,000 \\
\text { population }\end{array}$ & 0.4 & - & - & - & - & 0.52 \\
\hline $\begin{array}{l}1.1 \text { Krasno- } \\
\text { yarsk city }\end{array}$ & - & 1.0 & 0 & 2.520 & 3.721 & 0.52 \\
\hline $\begin{array}{l}1.2 \\
\text { Peschanka } \\
\text { village }\end{array}$ & - & 1.0 & 1.882 & 7.540 & 1.346 & 1.09 \\
\hline $\begin{array}{l}2 . \text { The num- } \\
\text { ber of fires } \\
\text { with deaths } \\
\text { per } 10,000 \\
\text { population }\end{array}$ & 0.3 & - & - & - & - & 0.44 \\
\hline $\begin{array}{l}2.1 \text { Krasno- } \\
\text { yarsk city }\end{array}$ & - & 0.8 & 0.005 & 0.041 & 0.058 & 0.44 \\
\hline $\begin{array}{l}2.2 \\
\text { Peschanka } \\
\text { village }\end{array}$ & - & 0.8 & 1.103 & 1.839 & 0 & 2.38 \\
\hline $\begin{array}{l}3 \text {. The num- } \\
\text { ber of fires } \\
\text { with casual- } \\
\text { ties per } \\
10000 \text { popu- } \\
\text { lation }\end{array}$ & 0.3 & - & - & - & - & 0.43 \\
\hline $\begin{array}{l}3.1 \text { Krasno- } \\
\text { yarsk city }\end{array}$ & - & 0.3 & 0.012 & 0.036 & 0.039 & 0.43 \\
\hline $\begin{array}{l}3.2 \\
\text { Peschanka } \\
\text { village }\end{array}$ & - & 0.3 & 0.755 & 2.115 & 0 & 1.84 \\
\hline
\end{tabular}

At the first stage, we calculate the estimates of the basic indicators, namely, the multidimensional estimates in the context of the two observation points (i.e. Krasnoyarsk city and Peschanka village), and then we aggregate them for the Krasnoyarsk area as a whole. Previously, we calculated the compliance coefficient according to Formula 5. As can be seen from Table 2, the actual values of indicators in Krasnoyarsk city are above the upper limits of the normative ranges, therefore, the compliance coefficient is calculated according to the second condition; the actual values of indicators in Peschanka village are below the lower limits of the ranges, therefore, the compliance coefficient is calculated according to the third condition. Thus, for "The number of household and industrial fires per 10,000 population" indicator in Krasnoyarsk city the compliance coefficient is identified as: 
$\Delta P_{11}=\left((3.721-2.52) /(2.52)^{1}=0.48\right.$; in Peschanka village the compliance coefficient is identified as: $\Delta P_{12}=\left((1.882-1.346) /(7.54-1.882)^{1}=-0.09\right.$. Taking into account the indicators trends, the estimate in Krasnoyarsk city is identified as: $i_{11}=1+1.48 \cdot(-1)=0.52$; the estimate in Peschanka village is identified as: $i_{12}=1+(-0.09) \cdot(-1)=1.09$. Analogically, we calculate the estimates for other indicators as follows: $i_{21}=0.44 ; i_{22}=2.38 ; i_{31}=0.43$ and $i_{32}=1.84$. The aggregation of the multidimensional estimates for considered indicators is defined by the "minimum" function (i.e. by the worst value recorded in observation points). Thus, the estimate of "The number of household and industrial fires per 10,000 population" indicator is $i_{1}=\min (0.52 ; 1.09)=0.52$. The estimates of "The number of fires with casualties per 10000 population" and "The number of fires with deaths per 10,000 population" indicators are $i_{2}=0.44$ and $i_{3}=0.43$ respectively.

At the second stage, we calculate the integral estimate of the "Fire situation" comprehensive indicator for the Krasnoyarsk area based on significance coefficients of basic indicators as follows: $I_{\text {Fire }}=0.4 \cdot 0.52+0.3 \cdot 0.44+0.3 \cdot 0.43=0.47$.

In accordance with the described algorithm, the integral estimates of all comprehensive indicators for the Krasnoyarsk area have been calculated. For anthropogenic safety indicators we have the following estimates: $I_{\text {TechObj }}=1.23, I_{\text {Transp }}=1.0$, $I_{\text {MunFacil }}=0.43, I_{\text {Rad }}=1.0$. For natural safety indicators we have the following estimates: $I_{\text {Meteo }}=1.17, I_{\text {Hydro }}=1.0, I_{\text {GeoPhys }}=1.0, I_{\text {ForestFire }}=1.05$. Integral estimates of the comprehensive indicators of higher level are calculated on the basis of significance coefficients of the comprehensive indicators of lower level as follows: $I_{\text {Anthr }}=0.97$, $I_{\text {Natur }}=1.06, I_{\text {NaturAnthr }}=0.99$. Estimation results show that the worst situation in Krasnoyarsk municipal area is observed for such indicators as "Fire situation" with $I_{\text {Fire }}=0.47$ and "Situation on the municipal facilities" with $I_{\text {MunFacil }}=0.43$, that require more careful study, special actions and measures aimed at improving the state of safety for this territory. However, the remaining indicators demonstrate the very good level of anthropogenic and natural safety. Moreover, some of them, such as "Situation on the technosphere objects" with $I_{\text {TechObj }}=1.23$, "Meteorological situation" with $I_{\text {Meteo }}=1.17$ and "Forest fire conditions" with $I_{\text {ForestFire }}=1.05$ show the significant improvement of safety according to normative values. As a result, we can see high values of estimates for comprehensive indicators and high level of safety state in general Krasnoyarsk municipal area.

The integral estimates of comprehensive indicators for all territories of the Krasnoyarsk region have been calculated similarly. Figure 4 represents the visualization of the integral estimation results on the geographic map. On this map, the green colour corresponds to the high values of the integral estimate, the yellow colour corresponds to the mean values of integral estimate and the red colour corresponds to the low values of integral estimates. 

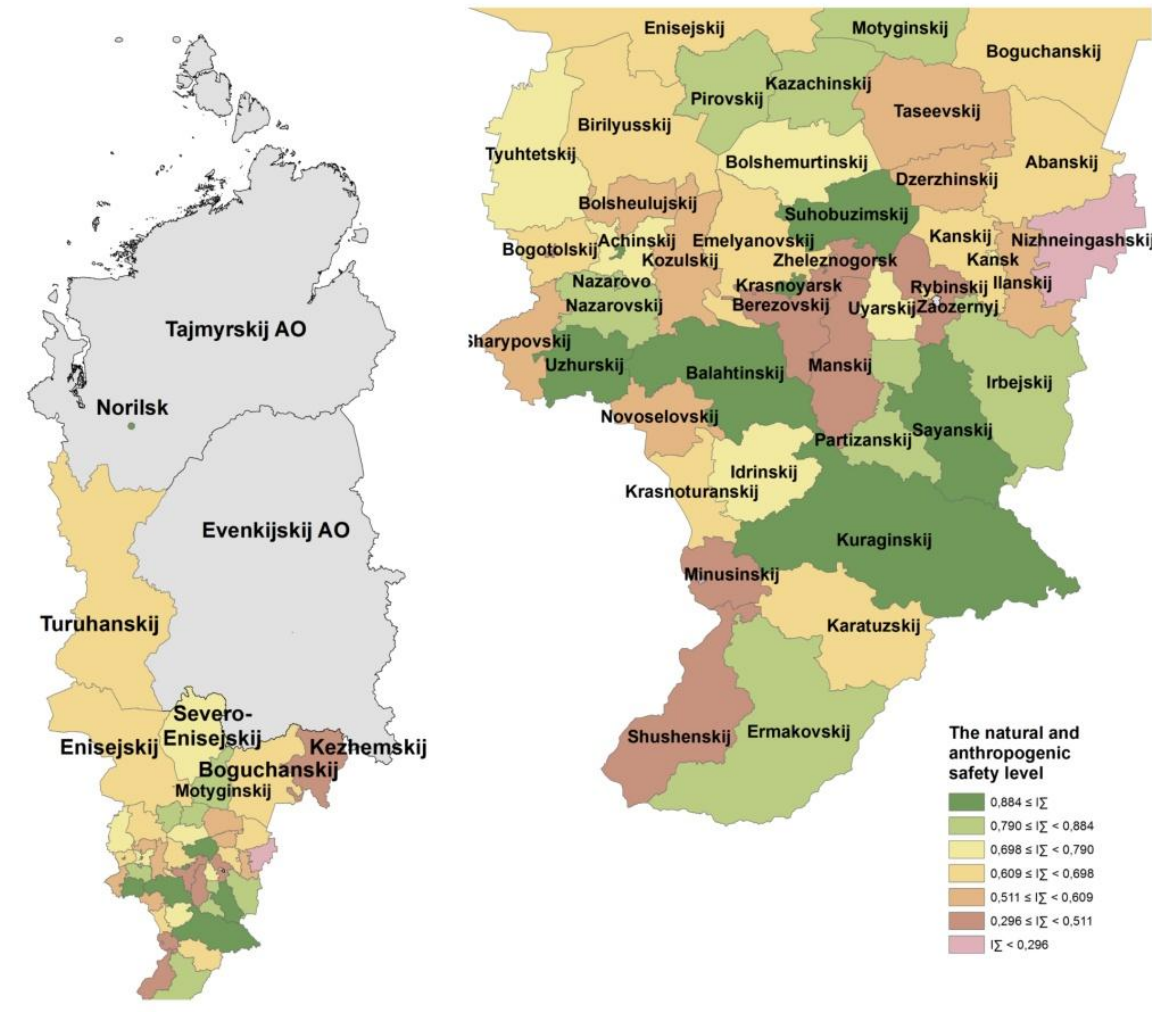

Fig. 4. Visualization of the integral estimation of the state of natural and antropogenic safety for terriotires of Krasnoyarsk region.

As can be seen, the best state of natural and anthropogenic safety is observed in central and northern groups of areas, including such cities as Yeniseisk, Lesosibirsk, Krasnoyarsk, as well as areas of Balakhta, Sukhobuzimsky and Kazachinsky. The worst state of the territory safety is observed in Nizhneingashsky area and Minusinsk city. The implementation of the proposed method gives the authority to control the state of safety of the territories, to detect the risk factors of the municipal areas and to form the basis for reasonable decision making.

\section{Conclusion}

This paper presents the method of comprehensive estimation of natural and anthropogenic territory safety that includes creation of the geographically-oriented safety standard and integral assessment of the state of the environment and technosphere objects. The standard presents a normative model that provides for correct estimation of the current safety state of the territory. In order to estimate the territory safety, the authors have proposed an algorithm which provides the calculation of integral esti- 
mate of the comprehensive indicator based on the multidimensional estimates of the basic indicators using the results of on-line analytical processing of monitoring data. The method allows for obtaining comprehensive quantitative characteristics of the state of territory safety, performing a comparative analysis and, if necessary, detailing the estimates for particular monitoring fields and indicators to identify the underlying causes of the current state. The implementation of the proposed method allows the decision maker to detect the risk factors and make reasonable control decisions.

The future research will be connected with validation of the normative model for Krasnoyarsk region territories and formalization of the basic processes of safety standard creation to will be able to apply proposed methodology to other regions. Development of estimation scale for semantic interpretation of quantitative estimates and development of methods for generating control recommendations based on results of comprehensive estimation and expert knowledge are planned as a future work.

\section{References}

1. Beroggi G., Wallace W.A.: Operational Risk Management: The Integration of Decision, Communications and Multimedia Technologies. Springer Science \& Business Media, (2012).

2. Haddow G., Bullock J., Coppola D.P.: Introduction to Emergency Management. Butterworth-Heinemann, (2017).

3. Mahutov N.A. Bezopasnost' i riski: sistemnyye issledovaniya i razrabotki [Safety and Risks: System Research and Development], Novosibirsk (2017) (in Russian).

4. Bolov V.R., Bogotyrev E.Ya., Bykov A.A. etc. Sovremennyye sistemy monitoringa i prognozirovaniya chrezvychaynykh situatsiy [Modern monitoring and forecasting system of emergencies], Moscow (2013) (in Russian).

5. Osipov V.I., Larionov V.I., Burova V.N., Frolova N.I., Sushchev S.P. Methodology of natural risk assessment in Russia. Natural hazards, N 8, vol.88, pp. 17-41 (2017). doi 10.1007/s11069-017-2780-z

6. Yamalov I.U. Modelirovaniye protsessov upravleniya i prinyatiya resheniy v usloviyakh chrezvychaynykh situatsiy [Modeling of management and decision-making processes in emergency situations], Moscow (2013) (in Russian).

7. Moskvichev V.V., Bychkov I.V., Potapov V.P., Taseiko O.V., Shokin Yu.I. Informatsionnaya sistema territorial'nogo upravleniya riskami razvitiya i bezopasnost'yu [Information system for territorial risk and safety management development]. Vestnik RAN [Herald of the Russian Academy of Sciences], N 8, vol. 87, pp. 696-705 (2017) (in Russian).

8. Faleev, M.I., Malyshev V.P., Makiev Yu.D etc. Ranneye preduprezhdeniye o chrezvychaynykh situatsiyakh [Early prevention of emergencies] (2015) (in Russian).

9. Penkova T., Nicheporchuk V., Metus A.: Comprehensive operational control of the natural and anthropogenic territory safety based on analytical indicators. ROUGH SETS, Lecture Notes in Artificial Intelligence, part I, vol.10313, pp. 263-270 (2017). doi 10.1007/978-3319-60837-2_22

10. Penkova T.G., Korobko A.V., Nicheporchuk V.V., Nozhenkova L.F. On-line modelling and assessment of the state of technosphere and environment objects based on monitoring data. KNOWLEDGE-BASED AND INTELLIGENT INFORMATION \& ENGINEERING SYSTEMS 18TH ANNUAL CONFERENCE, Procedia Computer Science, vol.35, pp. 156-165 (2014). doi 10.1016/j.procs.2014.08.095 
11. Metus A.M. Aktual'nyye zadachi kompleksnogo otsenivaniya prirodno-tekhnogennoy bezopasnosti territorii [Actual issues for comprehensive estimation of natural and technogenic safety of the territory]. Molodoy uchenyy [Young scientist], 11, pp. 89-92 (2015) (in Russian).

12. Gosudarstvennyy doklad o sostoyanii zashchity naseleniya i territoriy Krasnoyarskogo kraya ot chrezvychaynykh situatsiy prirodnogo i tekhnogennogo kharaktera: Glavnoye upravleniye MCHS Rossii po Krasnoyarskomu krayu [The State of Natural and Anthropogenic Emergencies Protection of Territory and Population in the Krasnoyarsk Region. Annual Report of Ministry of Emergency], Krasnoyarsk (2018) (in Russian).

13. Moskvichev V.V., Shokin Yu.I. Antropogennyye i prirodnyye riski na territorii Sibiri [Anthropogenic and natural risks on the territory of Siberia]. Vestnik RAN [Herald of the Russian Academy of Sciences], N 2, vol. 82, pp. 131-140 (2012) (in Russian).

14. Penkova T.G., Metus A.M. Kontseptual'naya model' integral'nogo analiticheskogo otsenivaniya prirodno-tekhnogennoy bezopasnosti territorii [Conceptual model of integral analytical estimation of natural and technogenic territory safety]. Informatizatsiya i svyaz' [Informatization and communication], N 2, pp. 65-71 (2016) (in Russian)..

15. Nicheporchuk V., Penkova T., Metus A. Formirovaniye standarta prirodno-tekhnogennoy bezopasnosti territoriy Krasnoyarskogo kraya [Formation of the standard of natural and technogenic safety of the Krasnoyarsk territory]. Problemy bezopasnosti i chrezvychaynykh situatsiy [Safety and emergencies problems], N 2, pp. 41-52 (2018) (in Russian).

16. Penkova T. Analysis of Natural and Technogenic Safety of the Krasnoyarsk Region Based on Data Mining Techniques. Lecture Notes in Computer Science: Advances in Conceptual Modeling, vol. 9975, pp. 102-112 (2016). doi 10.1007/978-3-319-47717-6_9.

17. Nicheporchuk V., Penkova T. Sistema analiticheskikh pokazateley dlya strategicheskogo kontrolya prirodno-tekhnogennoy bezopasnosti territoriy [The system of analytical indicators for strategic control of the natural and technogenic territory safety]. Problemy analiza riska [Issues of risk analysis], N 1, Vol. 15. pp. 70-77 (2018) (in Russian).

18. Glantz S.A. Primer of Biostatistics (1999).

19. Penkova T. Decision making support technique based on territory wellbeing estimation. INTELLIGENT DECISION TECHNOLOGIES, Smart Innovation, Systems and Technologies, vol. 39, pp. 513-523 (2015). doi 10.1007/978-3-319-19857-6_44

20. Penkova T. Method of Wellbeing Estimation in Territory Management. COMPUTATIONAL SCIENCE AND ITS APPLICATIONS, Lecture Notes in Computer Science, part IV, vol. 8582, pp. 57-68 (2014). doi 10.1007/978-3-319-09147-1_5 